\title{
Substrate-Dependent Sensitivity of SIRT1 to Nicotinamide Inhibition
}

\author{
Stacia Rymarchyk ${ }^{1}$, Wenjia Kang ${ }^{2}$ and Yana Cen ${ }^{2,3, *}$ \\ 1 Department of Pharmaceutical Sciences, Albany College of Pharmacy and Health Sciences, \\ Colchester, VT 05446, USA; srymarchyk@yahoo.com \\ 2 Department of Medicinal Chemistry, Virginia Commonwealth University, Richmond, VA 23219, USA; \\ kangw2@vcu.edu \\ 3 Institute for Structural Biology, Drug Discovery and Development, Virginia Commonwealth University, \\ Richmond, VA 23219, USA \\ * Correspondence: ceny2@vcu.edu; Tel.: +1-804-828-7405
}

Citation: Rymarchyk, S.; Kang, W.; Cen, Y. Substrate-Dependent Sensitivity of SIRT1 to Nicotinamide Inhibition. Biomolecules 2021, 11, 312. https://doi.org/10.3390/ biom11020312

Academic Editor: Umesh Desai

Received: 19 January 2021

Accepted: 16 February 2021

Published: 18 February 2021

Publisher's Note: MDPI stays neutral with regard to jurisdictional claims in published maps and institutional affiliations.

Copyright: () 2021 by the authors. Licensee MDPI, Basel, Switzerland. This article is an open access article distributed under the terms and conditions of the Creative Commons Attribution (CC BY) license (https:// creativecommons.org/licenses/by/ $4.0 /)$.

\begin{abstract}
SIRT1 is the most extensively studied human sirtuin with a broad spectrum of endogenous targets. It has been implicated in the regulation of a myriad of cellular events, such as gene transcription, mitochondria biogenesis, insulin secretion as well as glucose and lipid metabolism. From a mechanistic perspective, nicotinamide (NAM), a byproduct of a sirtuin-catalyzed reaction, reverses a reaction intermediate to regenerate $\mathrm{NAD}^{+}$through "base exchange", leading to the inhibition of the forward deacetylation. NAM has been suggested as a universal sirtuin negative regulator. Sirtuins have evolved different strategies in response to NAM regulation. Here, we report the detailed kinetic analysis of SIRT1-catalyzed reactions using endogenous substrate-based synthetic peptides. A novel substrate-dependent sensitivity of SIRT1 to NAM inhibition was observed. Additionally, SIRT1 demonstrated $\mathrm{pH}$-dependent deacetylation with normal solvent isotope effects (SIEs), consistent with proton transfer in the rate-limiting step. Base exchange, in contrast, was insensitive to $\mathrm{pH}$ changes with no apparent SIEs, indicative of lack of proton transfer in the rate-limiting step. Consequently, NAM inhibition was attenuated at a high $\mathrm{pH}$ in proteated buffers. Our study provides new evidence for "activation by de-repression" as an effective sirtuin activation strategy.
\end{abstract}

Keywords: SIRT1; epigenetics; deacetylation; NAM inhibition; base exchange; solvent isotope effect

\section{Introduction}

Human sirtuins are a group of $\mathrm{NAD}^{+}$-dependent protein lysine deacylases with distinct cellular compartmentalization and biological functions [1,2]. SIRT1, SIRT6 and SIRT7 are primarily localized in the nucleus, SIRT2 is mainly a cytosolic enzyme and SIRT3, SIRT4 and SIRT5 reside in the mitochondria [3,4]. By removing the acyl modifications from various cellular targets, sirtuins regulate diverse biological processes including metabolism [5,6], gene transcription [7], genome integrity [8] and cell cycle progression [9]. Interestingly, several human sirtuins have demonstrated increased gene expression or protein abundance in response to calorie restriction (CR) [10-12]. Sirtuin activities are thought to mediate the beneficial effects of CR in lifespan extension $[13,14]$. The last couple of decades have witnessed tremendous progress in understanding the function, disease relevance as well as developing small molecule regulators of human sirtuins [15-18].

The current study focuses on one particular human sirtuin isoform, SIRT1. Originally designated as a class III "histone deacetylase" (HDAC) [19,20], SIRT1 demonstrates good substrate tolerance by targeting a broad spectrum of cellular protein substrates, such as histones [21,22], transcription factors [23,24], tumor suppressors [25-27] and metabolic enzymes [28]. Through deacetylating the above-mentioned endogenous targets, SIRT1 exerts its far-reaching functions in insulin secretion [29], mitochondria biogenesis [30], DNA damage repair [31] and glucose metabolism [32]. Recent studies suggested that, in addition 
to the deacetylase activity, SIRT1 also removes acyl groups from lysine residues [33,34], although the physiological relevance of these novel posttranslational modifications are yet to be established.

Unlike the zinc-dependent HDACs, sirtuins employ a unique reaction mechanism for the seemingly simple deacetylation in which $\mathrm{NAD}^{+}$serves as the co-substrate (Scheme 1) [35]. Cleavage of the $\mathrm{N}$-glycosidic bond leads to the removal of nicotinamide (NAM) and the formation of an imidate intermediate. Subsequently, the imidate can be captured by the $2^{\prime}$-hydroxyl group of the ribose ring to generate a bicyclic intermediate. Ultimately, the collapse of the bicyclic intermediate gives rise to the deacetylated lysine product as well as a novel metabolite $O$-acetyl-ADPribose (AADPR). Detailed kinetic analysis indicated that NAM can intercept the imidate intermediate to regenerate $\mathrm{NAD}^{+}$through a "base exchange" process [36]. The unusual reaction mechanism allows sirtuin activity to be tightly regulated by both $\mathrm{NAD}^{+}$and NAM [37]. There is ample literature precedentsuggesting that sirtuins have evolved to respond to intracellular $\mathrm{NAD}^{+}$availability [38]. For example, inhibition of the critical $\mathrm{NAD}^{+}$biosynthetic enzyme, nicotinamide phosphoribosyltransferase (NAMPT), by small molecule FK866 significantly reduced the cellular NAD ${ }^{+}$contents, and subsequently suppressed mammalian sirtuin activity [39-41]. In contrast, boosting $\mathrm{NAD}^{+}$ levels with biosynthetic precursors, such as nicotinamide riboside (NR), has been shown to stimulate sirtuin activity $[42,43]$. It becomes clear that sirtuins serve as "NAD" sensors" to couple cellular energy status to their downstream signaling pathways.

NAM, on the other hand, has been suggested as a pan-sirtuin inhibitor [44,45]. It depletes the imidate intermediate to favor the reverse "base exchange", leading to inhibition of the forward deacetylation [36]. However, diverse NAM regulatory mechanisms have been observed for sirtuins. For mouse Sir $2 \alpha$ and human SIRT2, complete inhibition can be achieved with increasing concentrations of NAM [36,46]. Human SIRT6 and Archaeoglobus fulgidus Sir2 (Af2Sir2), on the contrary, were only partially inhibited even at millimolar NAM concentrations $[36,47]$. Furthermore, the distinct activities of human SIRT5 exhibited different sensitivities to NAM inhibition: the desuccinylase activity was potently suppressed by NAM, while deacetylation was quite inert to NAM treatment [48]. The differential regulation of sirtuin activity by NAM warrants thorough mechanistic investigations.

Herein, we report detailed kinetic analysis of the SIRT1-catalyzed reactions using physiologically relevant peptide substrates. Robust deacetylation was observed for all the peptide substrates examined, consistent with a previous study [49]. Intriguingly, SIRT1-mediated base exchange demonstrated substrate preference. Histone peptides and p53-based peptide strongly supported incorporation of exogenously added radiolabeled NAM into NAD ${ }^{+}$through base exchange. However, inefficient formation of radiolabeled $\mathrm{NAD}^{+}$was obtained when $\mathrm{p} 300$-based peptide was used. The efficiency of base exchange vs. deacetylation has been suggested as a predictor of NAM inhibition [36]. Indeed, with the addition of millimolar concentrations of NAM, the deacetylation of histone peptides and $\mathrm{p} 53$ peptide were almost completely inhibited, and the deacetylation of $\mathrm{p} 300$ peptide was partially inhibited. Furthermore, the $\mathrm{pH}$ profiles and solvent isotope effects (SIEs) of the deacetylation and base exchange were also investigated. Deacetylation was $\mathrm{pH}-$ dependent with a normal SIE, indicative of a rate-limiting step involving proton transfer mediated by a titratable group. Base exchange, however, was largely $\mathrm{pH}$-independent with no apparent SIE, consistent with the lack of proton transfer in the reaction mechanism. Collectively, our data suggested that NAM inhibition is governed by kinetic partitioning of the imidate intermediate, not by NAM binding per se.

\section{Materials and Methods}

\subsection{Reagents and Instrument}

All reagents were purchased from Aldrich (St. Louis, MO, USA) or Fisher Scientific (Pittsburgh, PA, USA) and were of the highest purity commercially available. UV spectra were obtained with a Varian Cary 300 Bio UV-visible spectrophotometer (Agilent Tech- 
nologies, Santa Clara, CA, USA). HPLC was performed on a Dionex Ultimate 3000 HPLC system (Thermo Electron, Madison, WI, USA) equipped with a diode array detector using a Macherey-Nagel C18 reverse-phase column (Macherey-Nagel, Bethlehem, PA, USA). Radiolabeled samples were counted in a Beckman LS6500 scintillation counter (Beckman, Indianapolis, IN, USA).

\subsection{Synthetic Peptides}

Synthetic peptides H3K9Ac: ARTKQTAR(K-Ac)STGGKAPRKQLAS, H4K16Ac: SGRGKGGKGLGKGGA(K-Ac)RHR, p300K1024Ac: ERSTELKTEI(K-Ac)EEEDQPSTS, p53K382Ac: KKGQSTSRHK(K-Ac)LMFKTEG were synthesized and purified by Genscript (Piscataway, NJ, USA). The peptides were purified by HPLC to a purity $>95 \%$.

\subsection{Protein Expression and Purification}

Plasmid of SIRT1 (full length) was the generous gift from Dr. Hening Lin (Cornell University). The protein was expressed and purified according to a previously published protocol (Figure S1) [50]. The identity of the protein was confirmed by tryptic digestion followed by LC-MS/MS analysis performed at the Vermont Genetic Network (VGN) Proteomics Facility. Protein concentration was determined by Bradford assay.

\subsection{Deacetylation Assay}

The $K_{\mathrm{m}}$ and $k_{\text {cat }}$ of SIRT1 were measured for the synthetic peptide substrates. A typical reaction was performed in $100 \mathrm{mM}$ phosphate buffer, $\mathrm{pH} 7.5$, in a total volume of $50 \mu \mathrm{L}$. The reactions contained $500 \mu \mathrm{M} \mathrm{NAD}^{+}$and increasing concentrations of peptide substrate. Reactions were initiated by the addition of $0.5 \mu \mathrm{M}$ of SIRT1 and were incubated at $37{ }^{\circ} \mathrm{C}$ for $10 \mathrm{~min}$ before being quenched by $8 \mu \mathrm{L}$ of $10 \%$ trifluoroacetic acid (TFA). The samples were then injected on an HPLC fitted to a Macherey-Nagel Nucleosil C18 column. The peaks of co-substrate $\mathrm{NAD}^{+}$and products nicotinamide (NAM) and O-acetylADP-ribose (AADPR) were resolved using a gradient of 0 to $20 \%$ methanol in $20 \mathrm{mM}$ ammonium acetate. Chromatograms were analyzed at $260 \mathrm{~nm}$. Reactions were quantified by integrating areas of peaks corresponding to $\mathrm{NAD}^{+}$and the deacetylation product AADPR. Rates were plotted as a function of substrate concentration and the best fit of the points to the Michaelis-Menten equation was performed by Kaleidagraph ${ }^{\circledR}$.

\subsection{Nicotinamide Inhibition Assay}

To determine nicotinamide inhibition, reactions were performed in $100 \mathrm{mM}$ phosphate buffer, $\mathrm{pH} 7.5$, containing $500 \mu \mathrm{M} \mathrm{NAD}^{+}, 500 \mu \mathrm{M}$ peptide substrate, and various concentrations of NAM. The reactions were initiated by the addition of $0.5 \mu \mathrm{M}$ of SIRT1 and were incubated at $37^{\circ} \mathrm{C}$ for $30 \mathrm{~min}$ before being quenched by $8 \mu \mathrm{L}$ of $10 \%$ TFA. The samples were then injected on an HPLC fitted to a Macherey-Nagel Nucleosil C18 column. Acetylated and deacetylated peptides were resolved using a gradient of $10 \%$ to $40 \%$ acetonitrile in $0.1 \%$ TFA. Chromatograms were analyzed at $215 \mathrm{~nm}$. Reactions were quantified by integrating area of peaks corresponding to acetylated and deacetylated peptides. Rates were plotted as a function of NAM concentration, and points were fitted to Equation (1):

$$
v=v_{0}-v_{i n h}\left(\frac{[I]}{K_{\mathrm{i}}+[I]}\right)
$$

where $v$ is the rate observed for a given concentration of NAM; $v_{0}$ is the uninhibited rate; $v_{\text {inh }}$ is the maximal inhibition; $K_{\mathrm{i}}$ is the apparent inhibition constant; and [I] is the concentration of NAM.

\section{6. ${ }^{14}$ C-Nicotinamide Base Exchange Assay}

The reactions were carried out in $100 \mathrm{mM}$ phosphate buffer, $\mathrm{pH} 7.5$, containing $500 \mu \mathrm{M} \mathrm{NAD}^{+}, 500 \mu \mathrm{M}$ peptide substrate, 300,000 cpm [carbonyl- $\left.{ }^{14} \mathrm{C}\right]$-nicotinamide $\left({ }^{14} \mathrm{C}\right.$ NAM, American Radiolabeled Chemicals Inc., St. Louis, MO, USA), and various concen- 
trations of NAM. The reactions were initiated by the addition of $0.5 \mu \mathrm{M}$ of SIRT1 and were incubated at $37^{\circ} \mathrm{C}$ for $10 \mathrm{~min}$ before being quenched by $8 \mu \mathrm{L}$ of $10 \%$ TFA. The samples were then injected on an HPLC fitted to a Macherey-Nagel Nucleosil C18 column. NAD ${ }^{+}$ and NAM were resolved using a gradient of 0 to $20 \%$ methanol in $0.1 \%$ TFA. Fractions containing NAM and $\mathrm{NAD}^{+}$were collected and the radioactivity determined by scintillation counting. Rates were expressed as cpm/s incorporated into $\mathrm{NAD}^{+}$, and converted to turnover rate $\left(\mathrm{s}^{-1}\right)$ after adjustment for specific radioactivity and enzyme concentration. Rates were plotted as a function of NAM concentration and the best fit of the points to the Michaelis-Menten equation was performed by Kaleidagraph ${ }^{\circledR}$.

\section{7. $p H$-Dependent Deacetylation Assay}

The $\mathrm{pH}$ effects on deacetylation was determined over a $\mathrm{pH}$ range of 6 to 9.5. Reactions contained $500 \mu \mathrm{M} \mathrm{NAD}^{+}$and $500 \mu \mathrm{M}$ p53K382Ac in a $100 \mathrm{mM}$ phosphate buffer of $\mathrm{pH}$ differing across the full $\mathrm{pH}$ range by $0.25 \mathrm{pH}$ units. The reactions were initiated by the addition of $0.5 \mu \mathrm{M}$ SIRT1 and incubated at $37^{\circ} \mathrm{C}$ for $10 \mathrm{~min}$ before being quenched by $8 \mu \mathrm{L}$ of $10 \%$ TFA. Product formation was quantified by HPLC assay as described above in the "Deacetylation Assay" section. Rates were plotted as a function of $\mathrm{pH}$, and points were fitted to Equation (2):

$$
\log k_{\mathrm{cat}}=\log k+\log \left(c /\left(1+\left[\mathrm{H}^{+}\right] / K_{\mathrm{a}}\right)\right)
$$

where $k$ is the rate at low $\mathrm{pH} ; k_{\text {cat }}$ is the observed rate at a given $\mathrm{pH} ; c$ is rate increment at high $\mathrm{pH}$; and $K_{\mathrm{a}}$ is the active site ionization constant.

\section{8. $p H$-Dependent Base Exchange Assay}

The $\mathrm{pH}$ effects on base exchange was determined over a $\mathrm{pH}$ range of 6 to 9.5. Reactions contained $500 \mu \mathrm{M} \mathrm{NAD}^{+}, 500 \mu \mathrm{M}$ p53K382Ac and $2 \mathrm{mM}^{14} \mathrm{C}-\mathrm{NAM}$ in a $100 \mathrm{mM}$ phosphate buffer of $\mathrm{pH}$ differing across the full $\mathrm{pH}$ range by $0.25 \mathrm{pH}$ units. The reactions were initiated by the addition of $0.5 \mu \mathrm{M}$ SIRT1 and incubated at $37^{\circ} \mathrm{C}$ for $10 \mathrm{~min}$ before being quenched by $8 \mu \mathrm{L}$ of $10 \%$ TFA. Product formation was quantified by HPLC assay as described above in the " ${ }^{14} \mathrm{C}-\mathrm{Nicotinamide}$ Base Exchange Assay" section. Rates were plotted as a function of $\mathrm{pH}$.

\subsection{Solvent Isotope Effects on Deacetylation}

Buffer components were added directly to $\mathrm{D}_{2} \mathrm{O}$, and the $\mathrm{pD}$ values were determined by adding 0.4 to the reading of the $\mathrm{pH}$ electrode [51]. The $\mathrm{pD}$ effects on deacetylation was determined over a $\mathrm{pD}$ range of 6 to 9.5. Reactions contained $500 \mu \mathrm{M} \mathrm{NAD}^{+}$and $500 \mu \mathrm{M}$ p53K382Ac in a $100 \mathrm{mM}$ phosphate buffer of $\mathrm{pD}$ differing across the full $\mathrm{pD}$ range by $0.25 \mathrm{pD}$ units. The reactions were initiated by the addition of $0.5 \mu \mathrm{M}$ SIRT1 and incubated at $37^{\circ} \mathrm{C}$ for $10 \mathrm{~min}$ before being quenched by $8 \mu \mathrm{L}$ of $10 \%$ TFA. Product formation was quantified by HPLC assay as described above in the "Deacetylation Assay" section. The rates were plotted as a function of $\mathrm{pD}$. The solvent isotope effects (SIEs) were expressed as $\mathrm{SIE}=k_{\mathrm{H} 2 \mathrm{O}} / k_{\mathrm{D} 2 \mathrm{O}}$.

\subsection{Solvent Isotope Effects on Base Exchange}

The SIE effect on base exchange was determined at $\mathrm{pH}(\mathrm{pD})$ 8.5. The reactions were carried out in a $100 \mathrm{mM}$ phosphate buffer containing $500 \mu \mathrm{M} \mathrm{NAD}^{+}, 500 \mu \mathrm{M}$ peptide substrate, $300,000 \mathrm{cpm}{ }^{14} \mathrm{C}-\mathrm{NAM}$, and various concentrations of NAM. The reactions were initiated by the addition of $0.5 \mu \mathrm{M}$ of SIRT1 and were incubated at $37^{\circ} \mathrm{C}$ for $10 \mathrm{~min}$ before being quenched by $8 \mu \mathrm{L}$ of $10 \%$ TFA. Product formation was quantified by HPLC assay as described above in the "14C-Nicotinamide Base Exchange Assay" section. Rates were plotted as a function of $\mathrm{pH}$ $(\mathrm{pD})$. The SIE was expressed as SIE $\left(k_{\text {cat }} / K_{\mathrm{m}}\right)=\left(k_{\text {cat }} / K_{\mathrm{m}}\right)^{\mathrm{H} 2 \mathrm{O}} /\left(k_{\mathrm{cat}} / K_{\mathrm{m}}\right)^{\mathrm{D} 2 \mathrm{O}}$. 


\section{Results and Discussions}

\subsection{SIRT1 Catalyzes Substrate-Dependent Base Exchange}

Among the seven human sirtuins, SIRT1 is the most studied isoform with a wealth of cellular targets [52]. Our initial effort focused on the biochemical characterization of recombinant SIRT1 activity using synthetic peptides derived from endogenous SIRT1 substrates including histones $\mathrm{H} 3$ and $\mathrm{H} 4$, tumor suppressor $\mathrm{p} 53$, and transcription coactivator p300. Table 1 lists the steady-state kinetic parameters for the SIRT1-catalyzed reactions. The deacetylation activity was evaluated using an HPLC-based assay as described in the "Materials and Methods" section. Full-length recombinant human SIRT1 was able to deacetylate all the peptide substrates examined in an $\mathrm{NAD}^{+}$-dependent fashion (Figure 1). The $K_{\mathrm{m}}$ values were determined to be $68.5 \pm 9.7 \mu \mathrm{M}$ for p53K328Ac, $79.6 \pm 10.8 \mu \mathrm{M}$ for H3K9Ac, $46.4 \pm 2.9 \mu \mathrm{M}$ for H4K16Ac and $60.9 \pm 6.7 \mu \mathrm{M}$ for p300K1024Ac, respectively. The $k_{\text {cat }}$ values were in the range from $0.093 \pm 0.003$ to $0.125 \pm 0.005 \mathrm{~s}^{-1}$. H4K16Ac demonstrated the highest catalytic efficiency of $2.67 \times 10^{-3} \mathrm{~s}^{-1} \mathrm{M}^{-1}, 1.7$ times higher than that of p53K382Ac, stemming primarily from the high binding affinity. Overall, the catalytic efficiency of the deacetylation was comparable for this panel of synthetic peptides.

Table 1. Recombinant SIRT1 steady-state parameters.

\begin{tabular}{|c|c|c|c|c|c|c|c|}
\hline \multirow[b]{2}{*}{ Substrate } & \multicolumn{3}{|c|}{ Deacetylation } & \multirow[b]{2}{*}{$\begin{array}{c}K_{\mathrm{i}(\mathrm{NAM})} \\
(\mu \mathrm{M})\end{array}$} & \multicolumn{3}{|c|}{ Base Exchange } \\
\hline & $K_{\mathrm{m}}(\mu \mathrm{M})$ & $k_{\text {cat }}\left(\mathrm{s}^{-1}\right)$ & $\begin{array}{c}k_{\mathrm{cat}} / K_{\mathrm{m}} \\
\left(10^{-3} \mathrm{~s}^{-1} \mathbf{M}^{-1}\right)\end{array}$ & & $K_{\mathrm{m}}(\mathrm{mM})$ & $k_{\text {cat }}\left(\mathrm{s}^{-1}\right)$ & $\begin{array}{c}k_{\mathrm{cat}} / K_{\mathrm{m}} \\
\left(10^{-3} \mathrm{~s}^{-1} \mathbf{M}^{-1}\right)\end{array}$ \\
\hline p53K382Ac & $68.5 \pm 9.7$ & $0.103 \pm 0.004$ & 1.50 & $294.4 \pm 44.6$ & $191.0 \pm 16.2$ & $0.905 \pm 0.020$ & 4.74 \\
\hline Н3К9Ас & $79.6 \pm 10.8$ & $0.125 \pm 0.005$ & 1.57 & $247.9 \pm 35.1$ & $271.5 \pm 18.8$ & $1.015 \pm 0.021$ & 3.74 \\
\hline H4K16Ac & $46.4 \pm 2.9$ & $0.124 \pm 0.002$ & 2.67 & $356.6 \pm 38.2$ & $284.2 \pm 22.1$ & $0.832 \pm 0.019$ & 2.93 \\
\hline p300K1024Ac & $60.9 \pm 6.7$ & $0.093 \pm 0.003$ & 1.53 & $336.1 \pm 68.7$ & $652.5 \pm 71.6$ & $0.509 \pm 0.022$ & 0.78 \\
\hline
\end{tabular}

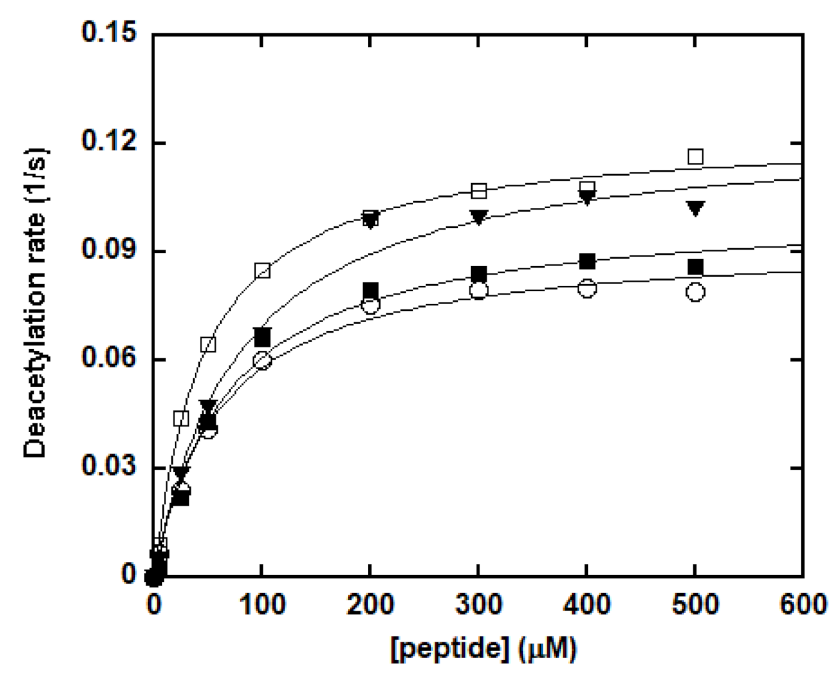

Figure 1. Steady-state kinetic analysis of SIRT1-catalyzed deacetylation. Peptide saturation curves for p53K382Ac (closed square), H3K9Ac (triangle), H4K16Ac (open square) and p300K1024Ac (circle). Reactions containing $500 \mu \mathrm{M} \mathrm{NAD}^{+}$, and various concentrations of peptide substrate in a $100 \mathrm{mM}$ phosphate buffer, $\mathrm{pH} 7.5$, were initiated by the addition of $0.5 \mu \mathrm{M}$ of SIRT1. The reactions were incubated at $37^{\circ} \mathrm{C}$ for $10 \mathrm{~min}$ and quenched by $8 \mu \mathrm{L}$ of $10 \%$ TFA. Rates were determined as described in the "Materials and Methods" section. Rates were plotted as a function of peptide concentration and fit to the Michaelis-Menten equation using Kaleidagraph ${ }^{\circledR}$.

The base exchange reactions were performed with SIRT1, saturating concentrations of $\mathrm{NAD}^{+}$and peptide substrate, $3 \times 10^{5} \mathrm{cpm}$ [carbonyl- ${ }^{14} \mathrm{C}$ ]-nicotinamide $\left({ }^{14} \mathrm{C}-\mathrm{NAM}\right)$ as well as increasing concentrations of NAM. NAD ${ }^{+}$and NAM were then resolved by 
HPLC, collected separately, and subjected to scintillation counting. Counts per minute (cpm) values were converted to the concentrations of ${ }^{14} \mathrm{C}-\mathrm{NAD}^{+}$for the calculation of the kinetic parameters. Surprisingly, SIRT1-catalyzed base exchange showed substrate preference (Figure 2 and Table 1). P300K1024Ac had the lowest catalytic efficiency of $0.78 \times 10^{-3} \mathrm{~s}^{-1} \mathrm{M}^{-1}$ with high $K_{\mathrm{m}}(652.5 \pm 71.6 \mu \mathrm{M})$ and low $k_{\text {cat }}\left(0.509 \pm 0.022 \mathrm{~s}^{-1}\right)$. The catalytic efficiency of H3K9Ac and H4K16Ac were $3.74 \times 10^{-3}$ and $2.93 \times 10^{-3} \mathrm{~s}^{-1} \mathrm{M}^{-1}$, respectively. The nearly 4.8 -fold and 3.8-fold increases compared to p300K1024Ac can be attributed to improved $K_{\mathrm{m}}$ and $k_{\text {cat }}$. More strikingly, p53K382Ac exhibited a nearly 6-fold increase in catalytic efficiency in comparison with p300K1024Ac, owing to a 3.4fold reduction of $K_{\mathrm{m}}(191.0 \pm 16.2 \mu \mathrm{M})$ and a 1.8-fold increase of $k_{\text {cat }}\left(0.905 \pm 0.020 \mathrm{~s}^{-1}\right)$. Previous characterizations of SIRT1 have been focusing on its deacetylase activity, which exhibits certain sequence selectivity $[53,54]$. Our study was the first one to illustrate the substrate-dependent base exchange activity of SIRT1, consistent with the partitioning behavior of the imidate intermediate (Scheme 1).

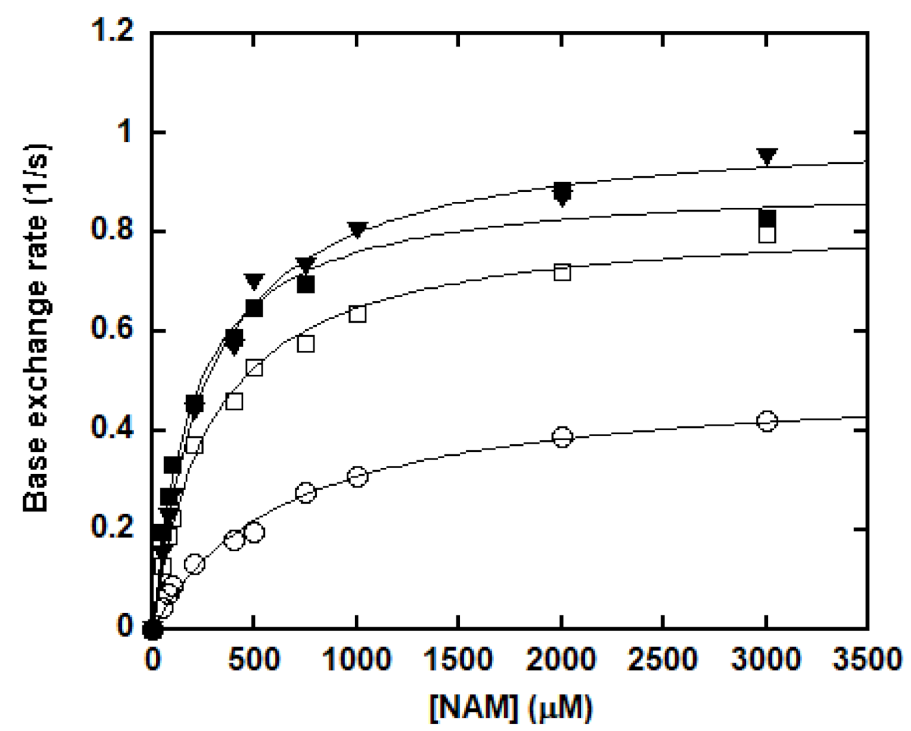

Figure 2. Kinetics of the SIRT1-catalyzed base exchange of ${ }^{14} \mathrm{C}-\mathrm{NAM}$ into unlabeled NAD ${ }^{+}$. The reactions were carried out in a $100 \mathrm{mM}$ phosphate buffer, $\mathrm{pH} 7.5$, containing $500 \mu \mathrm{M} \mathrm{NAD}^{+}, 500 \mu \mathrm{M}$ peptide substrate (p53K382Ac: closed square; H3K9Ac: triangle; H4K16Ac: open square; and p300K1024Ac: circle), 300,000 cpm ${ }^{14} \mathrm{C}-\mathrm{NAM}$, and various concentrations of NAM. The reactions were initiated by the addition of $0.5 \mu \mathrm{M}$ of SIRT1 and incubated at $37^{\circ} \mathrm{C}$ for $10 \mathrm{~min}$ before being quenched by $8 \mu \mathrm{L}$ of $10 \%$ TFA. Rates were determined as described in the "Materials and Methods" section and were plotted as a function of NAM concentration. The points were fitted to the MichaelisMenten equation using Kaleidagraph ${ }^{\circledR}$.

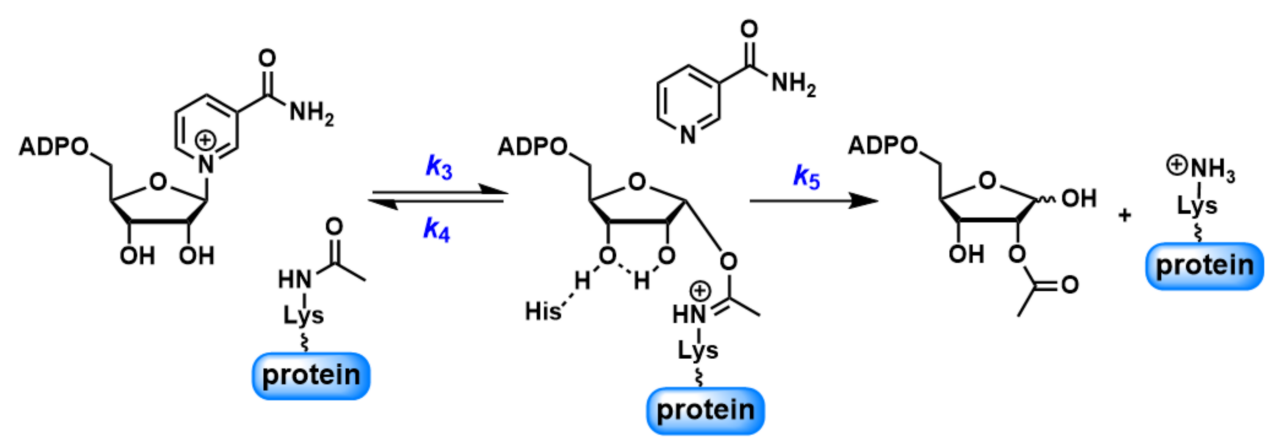

Scheme 1. Step-by-step mechanism of sirtuin-catalyzed $\mathrm{NAD}^{+}$-dependent protein deacetylation. 


\subsection{Peptide Substrates Demonstrate Differential Sensitivity to NAM Inhibition}

NAM is not only a byproduct, but also an inhibitor of sirtuin-catalyzed deacetylation $[36,46]$. NAM inhibition was assayed with saturating concentrations of $\mathrm{NAD}^{+}$and peptide, together with increasing concentrations of NAM as described in the "Materials and Methods" section. The percentage of remaining rate of deacetylation was plotted as a function of NAM concentration (Figure 3). Decreasing deacetylation was observed for all the peptide substrates with increasing levels of NAM. For p53K382Ac, H3K9Ac and H4K16Ac, greater than $80 \%$ inhibition occurred at high NAM concentration. However, NAM did not cause complete inhibition for p300K1024Ac. For this peptide, an approximately 55\% reduction of the deacetylation rate was obtained at millimolar NAM concentrations.

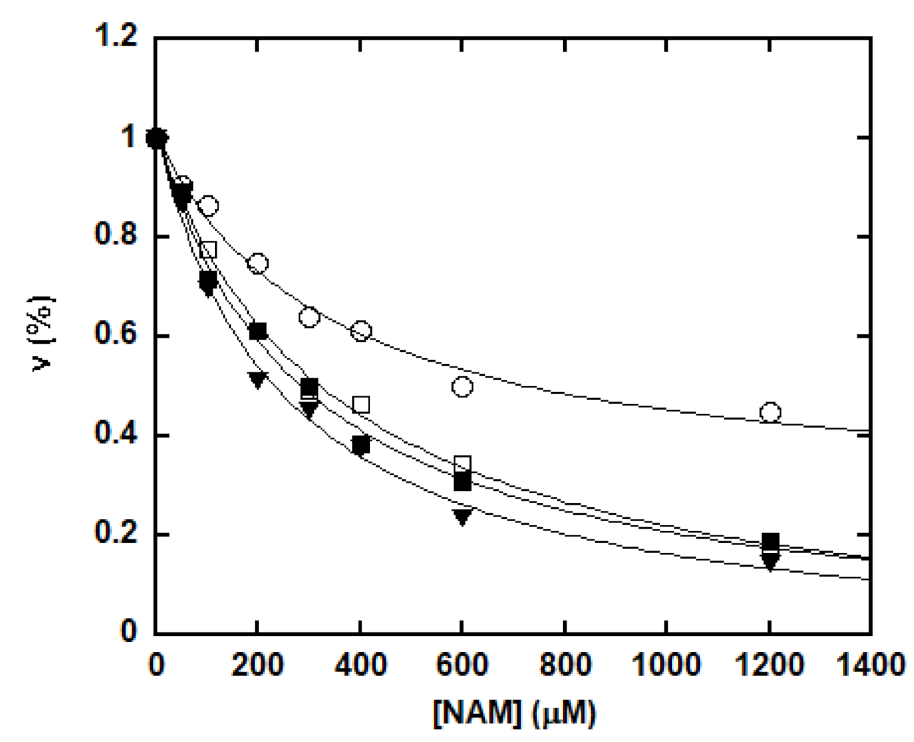

Figure 3. Inhibition of the deacetylation by increasing concentrations of NAM. The reactions were performed in a $100 \mathrm{mM}$ phosphate buffer, $\mathrm{pH} 7.5$, containing $500 \mu \mathrm{M} \mathrm{NAD}^{+}, 500 \mu \mathrm{M}$ peptide substrate (p53K382Ac: closed square; H3K9Ac: triangle; H4K16Ac: open square; and p300K1024Ac: circle) and various concentrations of NAM. The reactions were initiated by the addition of $0.5 \mu \mathrm{M}$ of SIRT1 and were incubated at $37^{\circ} \mathrm{C}$ for $30 \mathrm{~min}$ before being quenched by $8 \mu \mathrm{L}$ of $10 \%$ TFA. Rates were determined as described in the "Materials and Methods" section and were plotted as a function of NAM concentration. The points were fitted to the equation $v=v_{0}-v_{\text {inh }}\left(\frac{[I]}{K_{\mathrm{i}}+[I]}\right)$ using Kaleidagraph ${ }^{\circledR}$.

It has been suggested that forward deacetylation and reverse base exchange compete for the same imidate intermediate (Scheme 2) [36,46]. In other words, the rate of return to the Michaelis complex $\left(k_{4}\right)$ competes with the forward rate of nucleophilic attack of 2'-OH to the imidate $\left(k_{5}\right)$. If $k_{4}>k_{5}$, when sufficient NAM is available either at physiological NAM concentrations or near the $K_{\mathrm{i}(\mathrm{NAM})}$ of the enzyme, a significant fraction of imidate cannot proceed forward efficiently, leading to inhibition of the deacetylation. The $k_{\text {cat }}$ of deacetylation for SIRT1 was $\sim 0.1 \mathrm{~s}^{-1}$. All four peptides showed rapid base exchange rates in the range of 0.509 to $1.015 \mathrm{~s}^{-1}$, suggesting a kinetically competent reverse process. The $K_{\mathrm{i}(\mathrm{NAM})}$ values for p53K382Ac, H3K9Ac and H4K16Ac were 294.4 $\pm 44.6,247.9 \pm 35.1$ and $356.6 \pm 38.2 \mu \mathrm{M}$, respectively (Table 1 ), in good agreement with their $K_{\mathrm{m}}$ values for base exchange. P300K1024Ac exhibited the lowest $k_{\text {cat(exchange) }} / k_{\text {cat(deacetylation) }}$ of 5.5 , consistent with the partial inhibition observed at saturating NAM concentrations. 


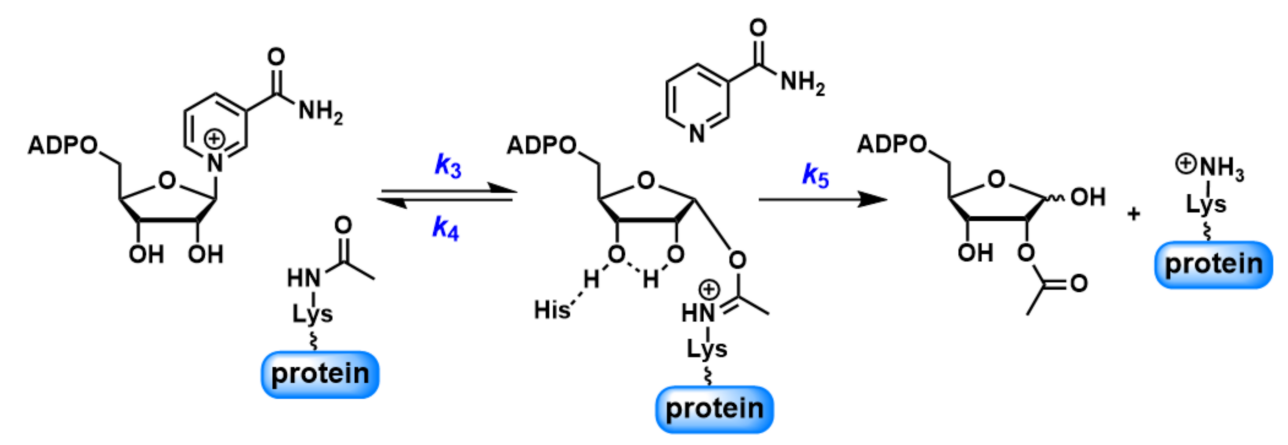

Scheme 2. Abbreviated scheme for the SIRT1-catalyzed reactions.

\subsection{SIRT1 Demonstrates $p H$-Dependent Deacetylation and $p H$-Independent Base Exchange}

To further probe the partitioning of the imidate intermediate, the $\mathrm{pH}$-dependence of both the deacetylation and base exchange was examined over a $\mathrm{pH}$ range of 6 to 9.5 using p53K382Ac as the substrate (Figure 4). Deacetylation was performed with saturating concentrations of $\mathrm{NAD}^{+}$and peptide in buffer solutions of $\mathrm{pH}$ differing across the full $\mathrm{pH}$ range by $0.25 \mathrm{pH}$ units. The deacetylation rate was largely unchanged between $\mathrm{pH} 6$ and 7 , and then increased in magnitude in a manner consistent with change in the protonation state of a titratable residue. The deacetylation rate increased approximately 14 -fold at $\mathrm{pH} 8.25$ and reached a plateau beyond this $\mathrm{pH}$. The $\mathrm{pH}$ profile of the deacetylation defined a critical ionization with a $\mathrm{p} K_{\mathrm{a}}$ value of 7.37, consistent with the $\mathrm{p} K_{\mathrm{a}}$ of an active site histidine (H363 for SIRT1), which was proposed to act as a general base to activate $2^{\prime}-\mathrm{OH}$ (Scheme 2) [55]. These results strongly support the notion that $k_{5}$, but not product release, is the rate-limiting step for deacetylation.

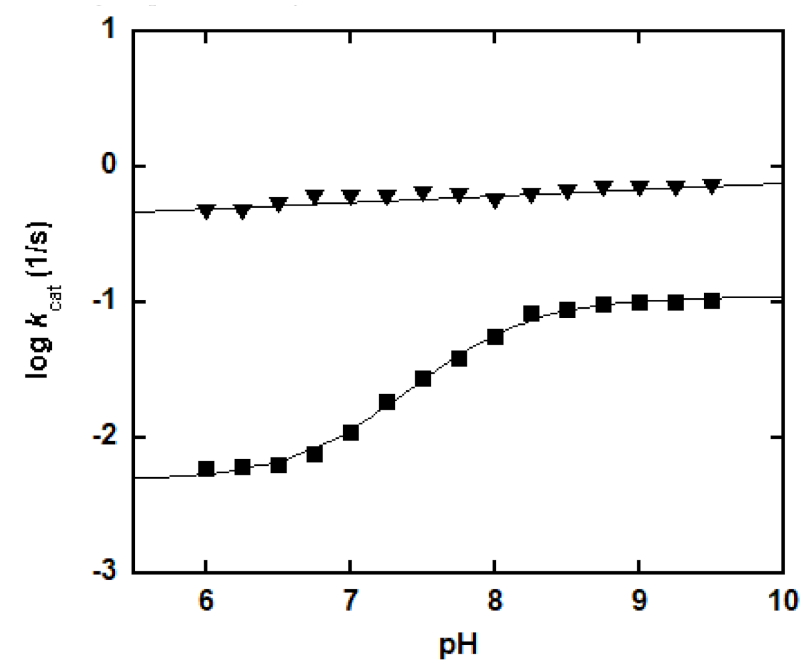

Figure 4. $\mathrm{pH}$ dependence of the SIRT1-catalyzed reactions. $\mathrm{pH}$ effects on the SIRT1-catalyzed deacetylation (closed square) and base exchange (triangle) were determined over a $\mathrm{pH}$ range of 6 to 9.5. The deacetylation reactions contained $500 \mu \mathrm{M} \mathrm{NAD}^{+}$and $500 \mu \mathrm{M}$ p53K382Ac in a $100 \mathrm{mM}$ phosphate buffer of $\mathrm{pH}$ differing across the full $\mathrm{pH}$ range by $0.25 \mathrm{pH}$ units. The reactions were initiated by the addition of $0.5 \mu \mathrm{M}$ SIRT1 and incubated at $37^{\circ} \mathrm{C}$ for $10 \mathrm{~min}$ before being quenched by $8 \mu \mathrm{L}$ of $10 \%$ TFA. Rates were determined as described in the "Materials and Methods" section and were plotted as a function of $\mathrm{pH}$. The points were fitted to the equation $\log k_{\text {cat }}=\log k+\log$ $\left(c /\left(1+\left[\mathrm{H}^{+}\right] / K_{\mathrm{a}}\right)\right)$ using Kaleidagraph ${ }^{\circledR}$. The $\mathrm{p} K_{\mathrm{a}}$ was determined to be 7.37 . The base exchange reactions contained $500 \mu \mathrm{M} \mathrm{NAD}^{+}, 500 \mu \mathrm{M}$ p53K382Ac and $2 \mathrm{mM}{ }^{14} \mathrm{C}-\mathrm{NAM}$ in a $100 \mathrm{mM}$ phosphate buffer of $\mathrm{pH}$ differing across the full $\mathrm{pH}$ range by $0.25 \mathrm{pH}$ units. The reactions were initiated by the addition of $0.5 \mu \mathrm{M}$ SIRT1 and incubated at $37^{\circ} \mathrm{C}$ for $10 \mathrm{~min}$ before being quenched by $8 \mu \mathrm{L}$ of $10 \%$ TFA. Rates were determined as described in the "Materials and Methods" section and were plotted as a function of $\mathrm{pH}$. The points were fitted to a linear line. 
In contrast, SIRT1-mediated base exchange was insensitive to $\mathrm{pH}$ changes (Figure 4). The rate of base exchange gradually increased with $\mathrm{pH}$, showing merely a 1.7-fold increase from $\mathrm{pH} 6$ to 9.5. The data were obtained with saturating concentrations of $\mathrm{NAD}^{+}$and peptide in combination of $2 \mathrm{mM}{ }^{14} \mathrm{C}-\mathrm{NAM}$. The steady-state kinetics of base exchange over a range of NAM concentrations was further evaluated at $\mathrm{pH} 6.5$ and 8.5 to confirm the $\mathrm{pH}$-independency (Figure S2). The $K_{\mathrm{m}}$ values remained roughly unchanged at different $\mathrm{pH}$ values $\left(118.6 \pm 11.1 \mu \mathrm{M}\right.$ at $\mathrm{pH} 6.5$, and $126.0 \pm 10.1 \mu \mathrm{M}$ at $\mathrm{pH} 8.5$, respectively). The $k_{\text {cat }}$ values increased from $0.616 \pm 0.016 \mathrm{~s}^{-1}$ at $\mathrm{pH} 6.5$ to $0.684 \pm 0.016 \mathrm{~s}^{-1}$ at $\mathrm{pH} 8.5$, consistent with the absence of proton transfer in the reverse process.

The $\mathrm{pH}$-dependence analysis revealed that $k_{5}$ increased with $\mathrm{pH}$, while $k_{4}$ remained nearly constant across the entire $\mathrm{pH}$ range examined (Scheme 2). Since imidate partitioning governs NAM inhibition, it was proposed that an increasing $\mathrm{pH}$ would weaken this inhibition. The NAM inhibition assays were performed at $\mathrm{pH} 6.5$ and 8.5 (Figure S3). With increasing concentrations of NAM, the residue deacetylation rate decreased at both $\mathrm{pH}$ values. However, the maximal inhibition at $1.2 \mathrm{mM}$ NAM declined from nearly $90 \%$ at $\mathrm{pH} 6.5$ to $68 \%$ at $\mathrm{pH} 8.5$, implying that elevating $\mathrm{pH}$ could serve as an effective strategy to relieve NAM inhibition.

\subsection{SIRT1-Catalyzed Deacetylation Exhibits Normal Solvent Isotope Effects (SIEs)}

SIEs are informative in determining the involvement of proton transfer in the ratelimiting step [51]. They can be expressed as a function of $\mathrm{pH}(\mathrm{pD})$ because of kinetically essential ionizations of exchangeable positions in either the enzyme or the substrate. The rate of deacetylation using p53K382Ac as the substrate was measured in $\mathrm{H}_{2} \mathrm{O}$ and $\mathrm{D}_{2} \mathrm{O}$ at various $\mathrm{pH}(\mathrm{pD})$ values between 6 and 9.5. Figure $5 \mathrm{~A}$ shows the plots of reaction rate as a function of $\mathrm{pH}(\mathrm{pD})$. Activity increased with the $\mathrm{pH}(\mathrm{pD})$ in either the proteated or deuterated buffers, and appeared to be lower in $\mathrm{D}_{2} \mathrm{O}$. Normal SIEs were detected at all the $\mathrm{pH}(\mathrm{pD})$ values and gradually declined from 9.4 at $\mathrm{pH}(\mathrm{pD}) 6$ to 2.1 at $\mathrm{pH}(\mathrm{pD}) 9.5$ (Figure 5B). Transfer of solvent-sensitive protons yields SIEs along the reaction coordinate. The results provided direct evidence of a kinetically significant ionization during the reaction, consistent with $k_{5}$ being rate-limiting since proton transfer mediated by $\mathrm{H} 363$ is inherent of the step (Scheme 2).

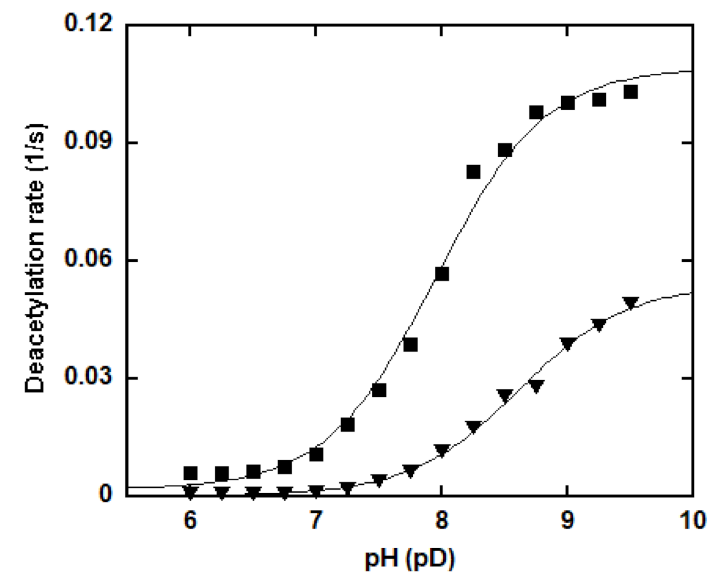

(A)

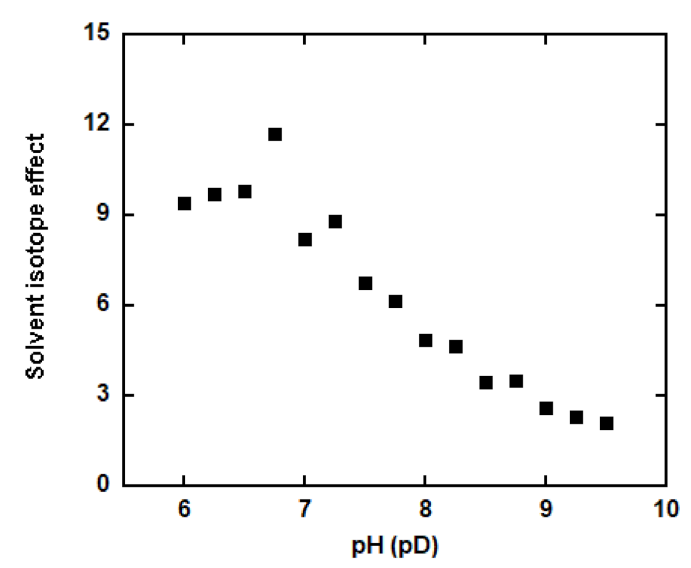

(B)

Figure 5. Solvent isotope effects of SIRT1-catalyzed deacetylation. (A) $\mathrm{pH}(\mathrm{pD}$ ) effects on deacetylation was determined over a $\mathrm{pH}(\mathrm{pD})$ range of 6 to 9.5 . Reactions contained $500 \mu \mathrm{M} \mathrm{NAD}^{+}$and $500 \mu \mathrm{M}$ p53K382Ac in a $100 \mathrm{mM}$ phosphate buffer of $\mathrm{pH}(\mathrm{pD})$ differing across the full $\mathrm{pH}(\mathrm{pD})$ range by $0.25 \mathrm{pH}(\mathrm{pD})$ units. The reactions were initiated by the addition of $0.5 \mu \mathrm{M}$ SIRT1 and incubated at $37^{\circ} \mathrm{C}$ for $10 \mathrm{~min}$ before being quenched by $8 \mu \mathrm{L}$ of $10 \%$ TFA. Rates were determined as described in the "Materials and Methods" section and plotted as a function of $\mathrm{pH}(\mathrm{pD})$. Closed square: in water; Triangle: in $\mathrm{D}_{2} \mathrm{O} ;(\mathbf{B})$ SIEs on deacetylation. The SIEs were expressed as SIE $=k_{\mathrm{H} 2 \mathrm{O}} / k_{\mathrm{D} 2 \mathrm{O}}$ and plotted as a function of $\mathrm{pH}(\mathrm{pD})$. 
Our previous study indicated that SIRT1-catalyzed base exchange was $\mathrm{pH}$-independent. No SIE was expected for this reverse process. The SIE on $k_{\text {cat }} / K_{\mathrm{m}}$ for base exchange at $\mathrm{pH}$ (pD) 8.5 was examined as described in the "Materials and Methods" section (Figure 6). The $k_{\text {cat }}$ and $K_{\mathrm{m}}$ at $\mathrm{pH} 8.5$ were determined to be $0.730 \pm 0.014 \mathrm{~s}^{-1}$ and $100.4 \pm 7.9 \mu \mathrm{M}$, respectively. The $k_{\text {cat }}$ and $K_{\mathrm{m}}$ at $\mathrm{pD} 8.5$ were $0.739 \pm 0.029 \mathrm{~s}^{-1}$ and $104.7 \pm 16.6 \mu \mathrm{M}$, respectively. The SIE $\left(k_{\text {cat }} / K_{\mathrm{m}}\right)$ was calculated to be $1.03 \pm 0.06$, in accord with proton transfernot being a kinetically significant step in base exchange. The absence of an SIE suggested that all the chemical steps are relatively fast compared to the steady-state rate of turnover.

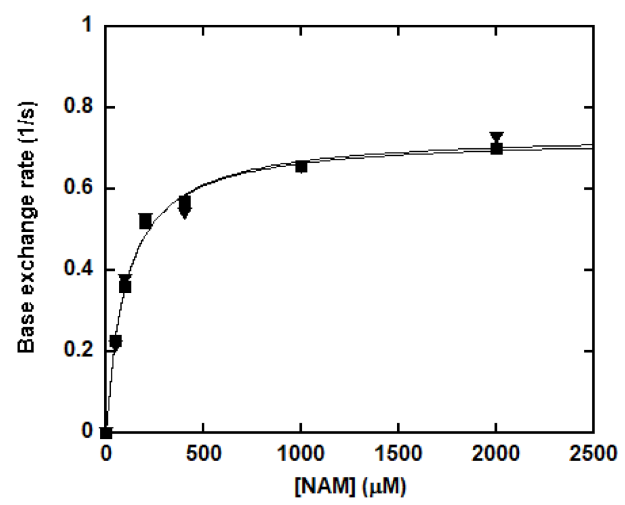

Figure 6. Solvent isotope effects (SIE) of SIRT1-catalyzed base exchange. The SIEs effect on base exchange was determined at $\mathrm{pH}(\mathrm{pD})$ 8.5. The reactions were carried out in a $100 \mathrm{mM}$ phosphate buffer containing $500 \mu \mathrm{M} \mathrm{NAD}{ }^{+}, 500 \mu \mathrm{M}$ peptide substrate, $300,000 \mathrm{cpm}{ }^{14} \mathrm{C}-\mathrm{NAM}$ and various concentrations of NAM. The reactions were initiated by the addition of $0.5 \mu \mathrm{M}$ of SIRT1 and were incubated at $37^{\circ} \mathrm{C}$ for $10 \mathrm{~min}$ before being quenched by $8 \mu \mathrm{L}$ of $10 \%$ TFA. Rates were determined as described in the "Materials and Methods" section and plotted as a function of NAM concentrations. Closed square: in water; Triangle: in $\mathrm{D}_{2} \mathrm{O}$.

The significant SIEs for deacetylation and the lack of SIEs for base exchange prompted us to investigate the SIEs on NAM inhibition of the forward deacetylation, which is inversely proportional to base exchange. NAM inhibition curves were obtained at $\mathrm{pH} 8.5$ and $\mathrm{pD} 8.5$ (Figure 7). The maximal inhibition improved from $68 \%$ at $\mathrm{pH} 8.5$ to greater than $90 \%$ at $\mathrm{pD} 8.5$, indicating NAM is a better inhibitor for the deacetylation reaction in $\mathrm{D}_{2} \mathrm{O}$.

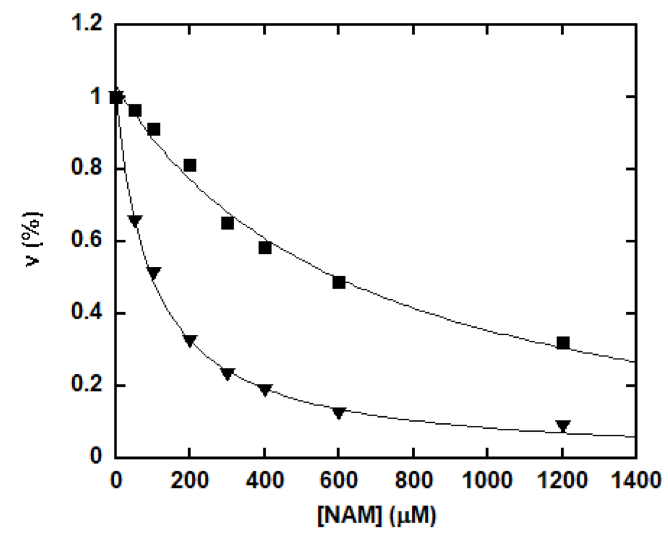

Figure 7. Solvent isotope effects of NAM inhibition. The reactions were performed in a $100 \mathrm{mM}$ phosphate buffer at $\mathrm{pH} 8.5$ (closed square) or pD 8.5 (triangle) containing $500 \mu \mathrm{M} \mathrm{NAD}^{+}, 500 \mu \mathrm{M}$ p53K382Ac and various concentrations of NAM. The reactions were initiated by the addition of $0.5 \mu \mathrm{M}$ of SIRT1 and were incubated at $37^{\circ} \mathrm{C}$ for $30 \mathrm{~min}$ before being quenched by $8 \mu \mathrm{L}$ of $10 \%$ TFA. Rates were determined as described in the "Materials and Methods" section and plotted as a function of NAM concentration. The points were fitted to the equation $v=v_{0}-v_{\text {inh }}\left(\frac{[I]}{K_{\mathrm{i}}+[I]}\right)$ using Kaleidagraph ${ }^{\circledR}$. 


\section{Conclusions and Perspectives}

SIRT1-catalyzed reactions couple $\mathrm{NAD}^{+}$and acetyllysine substrate to form an imidate intermediate. Subsequently, the imidate can either move forward for deacetylation or return backwards to reform $\mathrm{NAD}^{+}$through the "base exchange" process (Scheme 2). The imidate intermediate is long-lived to equilibrate NAM and serves as a "checkpoint" in the reaction mechanism [56]. The study of SIRT1 biochemical activity has been quite controversial. An early study suggested no substrate specificity for SIRT1 in vitro [49]. However, recent evidence indicated SIRT1 recognizes its substrate in a sequence-dependent manner [53,54]. It is important to point out that these previous studies have been focusing on the deacetylation activity. The substrate selectivity of base exchange has not been explored. In the current study, SIRT1-catalyzed reactions were investigated using a panel of synthetic peptide substrates based on several physiological SIRT1 targets. As one of the human sirtuins with robust deacetylase activity, SIRT1 was able to deacetylate both histone and non-histone peptides with high efficiency. Kinetically competent reverse base exchange reactions were also observed for all the peptide examined, with $k_{\text {cat(exchange) }} / k_{\text {cat(deacetylation) }}$ in the range of 5.5 to 8.8. Particularly, p300K1024Ac exhibited the lowest catalytic efficiency of base exchange, approximately 6 times lower than that of p53K382Ac. Inefficient base exchange implied resistance or insensitivity to NAM inhibition. Indeed, the deacetylation of p300K1024Ac cannot be completely inhibited at physiological NAM concentrations, in sharp contrast to the behaviors of other peptides.

In the deacetylation mechanism, a highly conserved active site histidine residue has been proposed to act as a general base to deprotonate and activate the $2^{\prime}-\mathrm{OH}$ of the ribose moiety for the subsequent nucleophilic attack of the imidate intermediate $[55,57,58]$. Our $\mathrm{pH}$-dependence study supported this hypothesis, as evidenced by the increased deacetylation rate with increasing $\mathrm{pH}$, which centered at $\mathrm{pH}$ of 7.37 , consistent with the $\mathrm{pK} \mathrm{a}_{\mathrm{a}}$ of the active site H363. Conversely, SIRT1-mediated base exchange was largely $\mathrm{pH}$ independent, indicating no significant participation of $\mathrm{H} 363$ in the reverse process. The decreased $k_{5} / k_{4}$ as a function of $\mathrm{pH}$ suggested that NAM inhibition can be weakened at elevated $\mathrm{pH}$. Indeed, the maximal inhibition at saturating NAM concentration was significantly reduced by going from $\mathrm{pH} 6.5$ to $\mathrm{pH} 8.5$.

To investigate the proton transfer step, SIEs were also measured. Normal SIEs were detected for deacetylation, further confirming that proton transfer is involved in the ratelimiting step for the forward reaction. The SIE measured for base exchange at $\mathrm{pH}(\mathrm{pD})$ 8.5 was close to unity, indicative of proton transfer not being a kinetically significant step for the reverse process. Furthermore, NAM inhibition was evaluated at $\mathrm{pH}(\mathrm{pD}) 8.5$. The inhibition was strengthened in the deuterated solvent, resulting in a $22 \%$ increase in maximal inhibition at millimolar NAM concentration.

"Activation by de-repression" has been proposed as an effective sirtuin activation strategy, as evidenced by the development of isonicotinamide as a sirtuin activator [37]. Alternatively, depletion of NAM by nicotinamidase, an enzyme responsible for converting NAM to nicotinic acid (NA), has been shown to activate Sir2 [59,60]. Our results suggested that NAM inhibition can also be relieved at elevated $\mathrm{pH}$ in proteated solvent, owing to the $\mathrm{pH}$-sensitive deacetylation and $\mathrm{pH}$-insensitive base exchange. $\mathrm{pH}$ engineering in enzyme microenvironment has been shown to enhance enzymatic activity [61,62]. For example, covalent conjugation of cytochrome $\mathrm{C}$ (cyt $\mathrm{C}$ ), an enzyme with an optimal $\mathrm{pH}$ of $\sim 4.5$, to highly negatively charged poly(methacrylic acid), created an acidic microenvironment near the enzyme active site. This modification led to a more than 2-fold activity increase compared to the unmodified enzyme [61]. Manipulating microenvironmental $\mathrm{pH}$ values also has significant therapeutic consequences. Alteration of tumor microenvironment $\mathrm{pH}$ values using small molecules such as bicarbonates and proton pump inhibitors offered a potential strategy to improve the efficacy of cancer therapy [63]. Our study not only revealed novel regulatory mechanism for mammalian sirtuins, but also opened new avenue of manipulating the $\mathrm{pH}$ profile to activate these enzymes. 
Supplementary Materials: The following are available online at https:/ / www.mdpi.com/2218-2 73X/11/2/312/s1, Figure S1: SDS-PAGE image of purified recombinant human SIRT1; Figure S2: SIRT1-catalyzed pH-independent base exchange; Figure S3: pH effects on NAM inhibition.

Author Contributions: Conceptualization, S.R. and Y.C.; formal analysis, Y.C.; funding acquisition, Y.C.; investigation, S.R. and W.K.; methodology, S.R. and W.K.; project administration, Y.C.; writing —original draft, Y.C.; writing-review and editing, Y.C. All authors have read and agreed to the published version of the manuscript.

Funding: This work was supported in part by CHE-1846785 from NSF to (Y.C.), Jeffress Trust Award in Interdisciplinary Research from Thomas F. and Kate Miller Jeffress Memorial Trust and Bank of America (to Y.C.), and 2020 Presidential Research Quest Fund from VCU (to Y.C.).

Institutional Review Board Statement: Not applicable.

Informed Consent Statement: Not applicable.

Data Availability Statement: The data presented in this study are available in the main text of this article and the supplementary material.

Conflicts of Interest: There are no conflict to declare.

\section{References}

1. Michan, S.; Sinclair, D. Sirtuins in mammals: Insights into their biological function. Biochem. J. 2007, 404, 1-13. [CrossRef] [PubMed]

2. Bheda, P.; Jing, H.; Wolberger, C.; Lin, H. The Substrate Specificity of Sirtuins. Annu. Rev. Biochem. 2016, 85, 405-429. [CrossRef] [PubMed]

3. Haigis, M.C.; Sinclair, D.A. Mammalian sirtuins: Biological insights and disease relevance. Annu. Rev. Pathol. 2010, 5, 253-295. [CrossRef] [PubMed]

4. Michishita, E.; Park, J.Y.; Burneskis, J.M.; Barrett, J.C.; Horikawa, I. Evolutionarily conserved and nonconserved cellular localizations and functions of human SIRT proteins. Mol. Biol. Cell 2005, 16, 4623-4635. [CrossRef] [PubMed]

5. Wang, C.; Liu, Y.; Zhu, Y.; Kong, C. Functions of mammalian SIRT4 in cellular metabolism and research progress in human cancer. Oncol. Lett. 2020, 20, 11. [CrossRef]

6. Chang, A.R.; Ferrer, C.M.; Mostoslavsky, R. SIRT6, a Mammalian Deacylase with Multitasking Abilities. Physiol. Rev. 2020, 100, 145-169. [CrossRef]

7. Kosciuk, T.; Wang, M.; Hong, J.Y.; Lin, H. Updates on the epigenetic roles of sirtuins. Curr. Opin. Chem. Biol. 2019, 51, 18-29. [CrossRef]

8. Bosch-Presegue, L.; Vaquero, A. Sirtuin-dependent epigenetic regulation in the maintenance of genome integrity. FEBS J. 2015, 282, 1745-1767. [CrossRef]

9. Wang, Y.; Yang, J.; Hong, T.; Chen, X.; Cui, L. SIRT2: Controversy and multiple roles in disease and physiology. Ageing Res. Rev. 2019, 55, 100961. [CrossRef]

10. Han, L.; Zhao, G.; Wang, H.; Tong, T.; Chen, J. Calorie restriction upregulated sirtuin 1 by attenuating its ubiquitin degradation in cancer cells. Clin. Exp. Pharmacol. Physiol. 2014, 41, 165-168. [CrossRef]

11. Kanfi, Y.; Shalman, R.; Peshti, V.; Pilosof, S.N.; Gozlan, Y.M.; Pearson, K.J.; Lerrer, B.; Moazed, D.; Marine, J.C.; de Cabo, R.; et al. Regulation of SIRT6 protein levels by nutrient availability. FEBS Lett. 2008, 582, 543-548. [CrossRef]

12. Palacios, O.M.; Carmona, J.J.; Michan, S.; Chen, K.Y.; Manabe, Y.; Ward, J.L., 3rd; Goodyear, L.J.; Tong, Q. Diet and exercise signals regulate SIRT3 and activate AMPK and PGC-1alpha in skeletal muscle. Aging (Albany N.Y.) 2009, 1, 771-783. [CrossRef]

13. Guarente, L. Calorie restriction and sirtuins revisited. Genes Dev. 2013, 27, 2072-2085. [CrossRef]

14. Zullo, A.; Simone, E.; Grimaldi, M.; Musto, V.; Mancini, F.P. Sirtuins as Mediator of the Anti-Ageing Effects of Calorie Restriction in Skeletal and Cardiac Muscle. Int. J. Mol. Sci. 2018, 19, 928. [CrossRef]

15. Liu, G.; Chen, H.; Liu, H.; Zhang, W.; Zhou, J. Emerging roles of SIRT6 in human diseases and its modulators. Med. Res. Rev. 2020. [CrossRef] [PubMed]

16. Kumar, S.; Lombard, D.B. Functions of the sirtuin deacylase SIRT5 in normal physiology and pathobiology. Crit. Rev. Biochem. Mol. Biol. 2018, 53, 311-334. [CrossRef] [PubMed]

17. Kumar, S.; Lombard, D.B. Mitochondrial sirtuins and their relationships with metabolic disease and cancer. Antioxid. Redox. Signal. 2015, 22, 1060-1077. [CrossRef]

18. Mautone, N.; Zwergel, C.; Mai, A.; Rotili, D. Sirtuin modulators: Where are we now? A review of patents from 2015 to 2019. Expert. Opin. Ther. Pat. 2020, 30, 389-407. [CrossRef] [PubMed]

19. Landry, J.; Sutton, A.; Tafrov, S.T.; Heller, R.C.; Stebbins, J.; Pillus, L.; Sternglanz, R. The silencing protein SIR2 and its homologs are NAD-dependent protein deacetylases. Proc. Natl. Acad. Sci. USA 2000, 97, 5807-5811. [CrossRef]

20. Imai, S.; Armstrong, C.M.; Kaeberlein, M.; Guarente, L. Transcriptional silencing and longevity protein Sir2 is an NAD-dependent histone deacetylase. Nature 2000, 403, 795-800. [CrossRef] [PubMed] 
21. Vaquero, A.; Scher, M.; Erdjument-Bromage, H.; Tempst, P.; Serrano, L.; Reinberg, D. SIRT1 regulates the histone methyltransferase SUV39H1 during heterochromatin formation. Nature 2007, 450, 440-444. [CrossRef] [PubMed]

22. Vaquero, A.; Scher, M.; Lee, D.; Erdjument-Bromage, H.; Tempst, P.; Reinberg, D. Human SirT1 interacts with histone H1 and promotes formation of facultative heterochromatin. Mol. Cell 2004, 16, 93-105. [CrossRef] [PubMed]

23. Motta, M.C.; Divecha, N.; Lemieux, M.; Kamel, C.; Chen, D.; Gu, W.; Bultsma, Y.; McBurney, M.; Guarente, L. Mammalian SIRT1 represses forkhead transcription factors. Cell 2004, 116, 551-563. [CrossRef]

24. Yeung, F.; Hoberg, J.E.; Ramsey, C.S.; Keller, M.D.; Jones, D.R.; Frye, R.A.; Mayo, M.W. Modulation of NF-kappaB-dependent transcription and cell survival by the SIRT1 deacetylase. EMBO J. 2004, 23, 2369-2380. [CrossRef] [PubMed]

25. Vaziri, H.; Dessain, S.K.; Ng Eaton, E.; Imai, S.I.; Frye, R.A.; Pandita, T.K.; Guarente, L.; Weinberg, R.A. hSIR2(SIRT1) functions as an NAD-dependent p53 deacetylase. Cell 2001, 107, 149-159. [CrossRef]

26. Dai, J.M.; Wang, Z.Y.; Sun, D.C.; Lin, R.X.; Wang, S.Q. SIRT1 interacts with p73 and suppresses p73-dependent transcriptional activity. J. Cell Physiol. 2007, 210, 161-166. [CrossRef]

27. Wang, C.; Chen, L.; Hou, X.; Li, Z.; Kabra, N.; Ma, Y.; Nemoto, S.; Finkel, T.; Gu, W.; Cress, W.D.; et al. Interactions between E2F1 and SirT1 regulate apoptotic response to DNA damage. Nat. Cell Biol. 2006, 8, 1025-1031. [CrossRef]

28. Hirschey, M.D.; Shimazu, T.; Capra, J.A.; Pollard, K.S.; Verdin, E. SIRT1 and SIRT3 deacetylate homologous substrates: AceCS1,2 and HMGCS1,2. Aging 2011, 3, 635-642. [CrossRef] [PubMed]

29. Liang, F.; Kume, S.; Koya, D. SIRT1 and insulin resistance. Nat. Rev. Endocrinol. 2009, 5, 367-373. [CrossRef]

30. Gurd, B.J. Deacetylation of PGC-1alpha by SIRT1: Importance for skeletal muscle function and exercise-induced mitochondrial biogenesis. Appl. Physiol. Nutr. Metab. 2011, 36, 589-597. [CrossRef]

31. Alves-Fernandes, D.K.; Jasiulionis, M.G. The Role of SIRT1 on DNA Damage Response and Epigenetic Alterations in Cancer. Int. J. Mol. Sci. 2019, 20, 3153. [CrossRef] [PubMed]

32. Choi, I.; Rickert, E.; Fernandez, M.; Webster, N.J.G. SIRT1 in Astrocytes Regulates Glucose Metabolism and Reproductive Function. Endocrinology 2019, 160, 1547-1560. [CrossRef]

33. Seidel, J.; Klockenbusch, C.; Schwarzer, D. Investigating Deformylase and Deacylase Activity of Mammalian and Bacterial Sirtuins. Chembiochem 2016, 17, 398-402. [CrossRef] [PubMed]

34. Feldman, J.L.; Baeza, J.; Denu, J.M. Activation of the protein deacetylase SIRT6 by long-chain fatty acids and widespread deacylation by mammalian sirtuins. J. Biol. Chem. 2013, 288, 31350-31356. [CrossRef] [PubMed]

35. Sauve, A.A.; Schramm, V.L. SIR2: The biochemical mechanism of NAD(+)-dependent protein deacetylation and ADP-ribosyl enzyme intermediates. Curr. Med. Chem. 2004, 11, 807-826. [CrossRef] [PubMed]

36. Sauve, A.A.; Schramm, V.L. Sir2 regulation by nicotinamide results from switching between base exchange and deacetylation chemistry. Biochemistry 2003, 42, 9249-9256. [CrossRef] [PubMed]

37. Sauve, A.A.; Moir, R.D.; Schramm, V.L.; Willis, I.M. Chemical activation of Sir2-dependent silencing by relief of nicotinamide inhibition. Mol. Cell 2005, 17, 595-601. [CrossRef] [PubMed]

38. Imai, S.I.; Guarente, L. It takes two to tango: $\mathrm{NAD}(+)$ and sirtuins in aging/longevity control. NPJ Aging Mech. Dis. 2016, 2, 16017. [CrossRef]

39. Yang, H.; Yang, T.; Baur, J.A.; Perez, E.; Matsui, T.; Carmona, J.J.; Lamming, D.W.; Souza-Pinto, N.C.; Bohr, V.A.; Rosenzweig, A.; et al. Nutrient-sensitive mitochondrial NAD+ levels dictate cell survival. Cell 2007, 130, 1095-1107. [CrossRef]

40. Skoge, R.H.; Dolle, C.; Ziegler, M. Regulation of SIRT2-dependent alpha-tubulin deacetylation by cellular NAD levels. DNA Repair 2014, 23, 33-38. [CrossRef]

41. Van Gool, F.; Galli, M.; Gueydan, C.; Kruys, V.; Prevot, P.P.; Bedalov, A.; Mostoslavsky, R.; Alt, F.W.; De Smedt, T.; Leo, O. Intracellular NAD levels regulate tumor necrosis factor protein synthesis in a sirtuin-dependent manner. Nat. Med. 2009, 15, 206-210. [CrossRef] [PubMed]

42. Canto, C.; Houtkooper, R.H.; Pirinen, E.; Youn, D.Y.; Oosterveer, M.H.; Cen, Y.; Fernandez-Marcos, P.J.; Yamamoto, H.; Andreux, P.A.; Cettour-Rose, P.; et al. The $\mathrm{NAD}(+)$ precursor nicotinamide riboside enhances oxidative metabolism and protects against high-fat diet-induced obesity. Cell Metab. 2012, 15, 838-847. [CrossRef] [PubMed]

43. Joshi, U.; Evans, J.E.; Pearson, A.; Saltiel, N.; Cseresznye, A.; Darcey, T.; Ojo, J.; Keegan, A.P.; Oberlin, S.; Mouzon, B.; et al. Targeting sirtuin activity with nicotinamide riboside reduces neuroinflammation in a GWI mouse model. Neurotoxicology 2020, 79, 84-94. [CrossRef] [PubMed]

44. Villalba, J.M.; Alcain, F.J. Sirtuin activators and inhibitors. Biofactors 2012, 38, 349-359. [CrossRef] [PubMed]

45. Avalos, J.L.; Bever, K.M.; Wolberger, C. Mechanism of sirtuin inhibition by nicotinamide: Altering the NAD(+) cosubstrate specificity of a Sir2 enzyme. Mol. Cell 2005, 17, 855-868. [CrossRef] [PubMed]

46. Jackson, M.D.; Schmidt, M.T.; Oppenheimer, N.J.; Denu, J.M. Mechanism of nicotinamide inhibition and transglycosidation by Sir2 histone/protein deacetylases. J. Biol. Chem. 2003, 278, 50985-50998. [CrossRef]

47. Wood, M.; Rymarchyk, S.; Zheng, S.; Cen, Y. Trichostatin A inhibits deacetylation of histone H3 and p53 by SIRT6. Arch. Biochem. Biophys. 2018, 638, 8-17. [CrossRef]

48. Fischer, F.; Gertz, M.; Suenkel, B.; Lakshminarasimhan, M.; Schutkowski, M.; Steegborn, C. Sirt5 deacylation activities show differential sensitivities to nicotinamide inhibition. PLoS ONE 2012, 7, e45098. [CrossRef] [PubMed]

49. Blander, G.; Olejnik, J.; Krzymanska-Olejnik, E.; McDonagh, T.; Haigis, M.; Yaffe, M.B.; Guarente, L. SIRT1 shows no substrate specificity in vitro. J. Biol. Chem. 2005, 280, 9780-9785. [CrossRef] 
50. Du, J.; Jiang, H.; Lin, H. Investigating the ADP-ribosyltransferase activity of sirtuins with NAD analogues and 32P-NAD. Biochemistry 2009, 48, 2878-2890. [CrossRef]

51. Schowen, K.B.; Schowen, R.L. Solvent isotope effects of enzyme systems. Methods Enzymol. 1982, 87, 551-606.

52. Cen, Y.; Youn, D.Y.; Sauve, A.A. Advances in characterization of human sirtuin isoforms: Chemistries, targets and therapeutic applications. Curr. Med. Chem. 2011, 18, 1919-1935. [CrossRef] [PubMed]

53. Rauh, D.; Fischer, F.; Gertz, M.; Lakshminarasimhan, M.; Bergbrede, T.; Aladini, F.; Kambach, C.; Becker, C.F.; Zerweck, J.; Schutkowski, M.; et al. An acetylome peptide microarray reveals specificities and deacetylation substrates for all human sirtuin isoforms. Nat. Commun. 2013, 4, 2327. [CrossRef] [PubMed]

54. Garske, A.L.; Denu, J.M. SIRT1 top 40 hits: Use of one-bead, one-compound acetyl-peptide libraries and quantum dots to probe deacetylase specificity. Biochemistry 2006, 45, 94-101. [CrossRef] [PubMed]

55. Smith, B.C.; Denu, J.M. Sir2 protein deacetylases: Evidence for chemical intermediates and functions of a conserved histidine. Biochemistry 2006, 45, 272-282. [CrossRef] [PubMed]

56. Sauve, A.A.; Wolberger, C.; Schramm, V.L.; Boeke, J.D. The biochemistry of sirtuins. Annu. Rev. Biochem. 2006, 75, 435-465. [CrossRef]

57. Sauve, A.A.; Celic, I.; Avalos, J.; Deng, H.; Boeke, J.D.; Schramm, V.L. Chemistry of gene silencing: The mechanism of NAD+dependent deacetylation reactions. Biochemistry 2001, 40, 15456-15463. [CrossRef]

58. Min, J.; Landry, J.; Sternglanz, R.; Xu, R.M. Crystal structure of a SIR2 homolog-NAD complex. Cell 2001, 105, 269-279. [CrossRef]

59. Anderson, R.M.; Bitterman, K.J.; Wood, J.G.; Medvedik, O.; Sinclair, D.A. Nicotinamide and PNC1 govern lifespan extension by calorie restriction in Saccharomyces cerevisiae. Nature 2003, 423, 181-185. [CrossRef]

60. Gallo, C.M.; Smith, D.L., Jr.; Smith, J.S. Nicotinamide clearance by Pnc1 directly regulates Sir2-mediated silencing and longevity. Mol. Cell Biol. 2004, 24, 1301-1312. [CrossRef]

61. Zhang, Y.F.; Wang, Q.; Hess, H. Increasing Enzyme Cascade Throughput by pH-Engineering the Microenvironment of Individual Enzymes. Acs Catal. 2017, 7, 2047-2051. [CrossRef]

62. Lancaster, L.; Abdallah, W.; Banta, S.; Wheeldon, I. Engineering enzyme microenvironments for enhanced biocatalysis. Chem. Soc. Rev. 2018, 47, 5177-5186. [CrossRef] [PubMed]

63. Hao, G.Y.; Xu, Z.P.; Li, L. Manipulating extracellular tumour pH: An effective target for cancer therapy. RSC Adv. 2018, 8, 22182-22192. [CrossRef] 